\title{
Uncertainty Analysis in Life Cycle Assessment (LCA): Case Study on Plant - Protection Products and Implications for Decision Making
}

Other Journal Item

Author(s):

Geisler, Georg; Hellweg, Stefanie (1); Hungerbühler, Konrad

Publication date:

2005

Permanent link:

https://doi.org/10.3929/ethz-b-000423086

Rights / license:

In Copyright - Non-Commercial Use Permitted

Originally published in:

The International Journal of Life Cycle Assessment 10(3), https://doi.org/10.1065/lca2004.09.178.1 


\title{
Supporting Information
}

\section{Uncertainty Analysis in Life Cycle Assessment (LCA): Case Study on Plant Protection Products and Implications for Decision Making}

\author{
Georg Geisler ${ }^{1}$, Stefanie Hellweg ${ }^{1 *}$ and Konrad Hungerbühler ${ }^{1}$ \\ ${ }^{1}$ Institute for Chemical- and Bioengineering, Swiss Federal Institute of Technology, ETH-Hönggerberg, CH-8093 Zürich, Switzerland
}

* Corresponding author (Stefanie.hellweg@chem.ethz.ch)

\section{DOI: http://dx.doi.org/10.1065/lca2004.09.178. 1}

\section{Generic Dispersion Factors for Elementary Flows}

Elementary flows were compared in LCIs of sodium hydroxide and benzene production from different sources in order to derive generic dispersion factors (Equation 2 main article) for groups of these flows. Sources of the LCI datasets compared are shown in Table $\mathbf{S} 1$.

To calculate the dispersion factors listed in Table 2 (main article, DOI: http://dx.doi.org/10.1065/lca2004.09.178), the nomenclature of elementary flows and sum parameters was first harmonised between the LCIs in Table S1. All energy flows were then converted to primary energy demands [1] and divided into feedstock and energy supply use. Finally, dispersion factors (Equation 2 main article) were calculated for all elementary flows. Elementary flows with values below $10^{-10} \mathrm{~kg} / \mathrm{kg}_{\text {product }}$ were excluded because such low values are likely to be calculation artefacts.

\section{Probability Distributions for Parameters in the LCA Model}

Generic dispersion factors (Equation 2, main article, DOI: http://dx. doi.org/10.1065/lca2004.09.178) were used to parameterise lognormal distributions for most parameters in the LCA of the case study. Dispersion factors are documented in Table S2 concerning characterisation factors of the CML-baseline method [12]. Additional uncertainty in the composition of sum parameters was depicted as uniform distributions (see main article), the minimum and maximum values of which are documented in Table S3. To determine these values, first a set of substances contained in each sum parameter was chosen from all substances characterised in the CML-baseline method [13]. From these sets of substances, the minimum and maximum characterisation factors were then determined for each sum parameter. Finally, several parameters in the LCA model were based on data specifically acquired. Uncertainty in these parameters was assessed by statistical fitting of probability distributions, where enough data was available. In most cases, however, only few data were available, and therefore lognormal distributions were parameterised using dispersion factors (Equation 2, main article, DOI: http://dx.doi.org/10.1065/lca2004.09.178). Resulting distributions for parameters with some importance in the assessment are documented in Fig. S1. Dose distributions were calculated from dose ranges recommended by pesticide registration

Table S1: Sources of LCls used to derive generic dispersion factors for elementary flows, including the number of of LCls from independent data sources. APME is a successor organisation of PWMI

\begin{tabular}{|c|c|c|c|c|c|}
\hline Product & $\begin{array}{c}\text { Number of } \\
\text { LCls compared }\end{array}$ & $\begin{array}{c}\text { Number of independent } \\
\text { data sources }\end{array}$ & $\begin{array}{l}\text { LCl identifier in } \\
\text { Simapro [2] }\end{array}$ & $\begin{array}{l}\text { Secondary } \\
\text { data sources }\end{array}$ & $\begin{array}{l}\text { Primary } \\
\text { data source }\end{array}$ \\
\hline \multirow[t]{6}{*}{ Benzene } & 6 & 2 & Benzene A & pré [2] & APME [3] \\
\hline & & & Benzene P & [2] & PWMI [4] \\
\hline & & & Benzene P (1997) & [2] & APME [5] \\
\hline & & & Benzene I & IDEMAT [6] & [4] \\
\hline & & & Benzene B250 (1998) & BUWAL [7] & [3] \\
\hline & & & Benzene bj & Bergh and Juergens [8] & [8] \\
\hline \multirow{9}{*}{$\begin{array}{l}\text { Sodium } \\
\text { hydroxide }\end{array}$} & 9 & 3 & $\mathrm{NaOH}$ average Europe $\mathrm{P}$ & pré [2] & [3] \\
\hline & & & $\mathrm{NaOH} P(1998)$ & $\begin{array}{c}\text { pré [2] } \\
\text { (revised data) }\end{array}$ & [3] \\
\hline & & & $\mathrm{NaOH}$ ETH T & Frischknecht et al. [1] & [3] \\
\hline & & & $\mathrm{NaOH}(100 \%)$ & BUWAL [9] & [3] \\
\hline & & & $\mathrm{NaOH}$ bj & Bergh and Juergens [10] & {$[10]$} \\
\hline & & & $\mathrm{NaOH}$ (diaphragm) & [2] & spin [11] \\
\hline & & & $\mathrm{NaOH}$ (membrane) & [2] & [11] \\
\hline & & & $\mathrm{NaOH}$ (mercury) & [2] & [11] \\
\hline & & & $\mathrm{NaOH}$ average $\mathrm{NL}$ & [2] & [11] \\
\hline
\end{tabular}


Table S2: Generic dispersion factors (Equation 2 main article) for characterisation factors in the impact categories of the CML-baseline method, from Huijbregts [14]. Coefficients of variation calculated according to [15]

\begin{tabular}{|c|c|c|c|}
\hline Impact category & Cases & Dispersion factor & CV, dimensionless \\
\hline \multirow{2}{*}{$\begin{array}{l}\text { Terrestrial ecotoxicity } \\
\text { potential }\end{array}$} & Emission to air or soil & 500 & 159 \\
\hline & Emission to other compartments & 1000 & 500 \\
\hline \multirow{2}{*}{$\begin{array}{l}\text { Freshwater ecotoxicity } \\
\text { potential }\end{array}$} & Emission to air or fresh water & 50 & 10 \\
\hline & Emission to other compartments & 100 & 150 \\
\hline Human toxicity potential & Emission to any compartment & 50 & 10 \\
\hline \multirow{2}{*}{$\begin{array}{l}\text { Global warming } \\
\text { potential }\end{array}$} & Substances with net positive radiative forcing & 1.4 & 0.17 \\
\hline & $\mathrm{CO}_{2}$ as reference substance & None & None \\
\hline \multirow{3}{*}{$\begin{array}{l}\text { Photooxidant creation } \\
\text { potential }\end{array}$} & $\mathrm{k}_{\mathrm{OH}}<4.0 \mathrm{E}-13 \mathrm{~cm}^{3} /($ molecule $\mathrm{s})$ & 2.1 & 0.39 \\
\hline & $\left(4.0 \mathrm{E}-13<\mathrm{koH}_{\mathrm{OH}}<4.0 \mathrm{E}-11\right) \mathrm{cm}^{3} /($ molecule $\mathrm{s})$ & $\mathrm{k}=-0.2 * \ln \left(\mathrm{k}_{\mathrm{OH}}\right)-3.5$ & Substance-dependent \\
\hline & $\mathrm{k}_{\mathrm{OH}}>4.0 \mathrm{E}-11 \mathrm{~cm}^{3} /($ molecule s) & 1.2 & 0.09 \\
\hline Acidification potential & None & 2.2 & 0.42 \\
\hline Eutrophication potential & None & 1.8 & 0.31 \\
\hline
\end{tabular}

Table S3: Characterisation factors for sum parameters. The minimum and maximum characterization factor of components of each sum parameter were used to define a uniform distribution that depicts the uncertainty due to the unknown composition of the sum parameter

\begin{tabular}{|c|c|c|c|c|c|c|c|c|}
\hline \multirow[t]{2}{*}{ Sum parameter name } & \multicolumn{2}{|c|}{$\begin{array}{c}\text { Photooxidant creation } \\
\text { potential }\end{array}$} & \multicolumn{2}{|c|}{$\begin{array}{l}\text { Human toxicity } \\
\text { potential }\end{array}$} & \multicolumn{2}{|c|}{$\begin{array}{c}\text { Freshwater ecotoxicity } \\
\text { potential }\end{array}$} & \multicolumn{2}{|c|}{$\begin{array}{c}\text { Terrestrial ecotoxicity } \\
\text { potential }\end{array}$} \\
\hline & Minimum & Maximum & Minimum & Maximum & Minimum & Maximum & Minimum & Maximum \\
\hline \multicolumn{9}{|c|}{ Emissions to air } \\
\hline Aldehydes & $5.1 \mathrm{E}-01$ & 8.0E-01 & 8.3E-01 & $5.7 \mathrm{E}+01$ & $8.3 \mathrm{E}+00$ & $5.2 \mathrm{E}+02$ & $9.4 \mathrm{E}-01$ & $1.6 \mathrm{E}+01$ \\
\hline Alkanes & $1.2 \mathrm{E}-01$ & $1.1 \mathrm{E}+00$ & & & & & & \\
\hline Alkenes & 6.3E-01 & $1.1 \mathrm{E}+00$ & 4.3E-03 & $9.6 \mathrm{E}+01$ & & & 8.7E-15 & 2.0E-10 \\
\hline Alcohols & $1.1 \mathrm{E}-01$ & $6.2 \mathrm{E}-01$ & & & & & & \\
\hline Cfc(soft) & & & $6.8 \mathrm{E}+00$ & $3.4 \mathrm{E}+01$ & 3.8E-05 & $1.2 \mathrm{E}-04$ & 4.7E-06 & $1.8 \mathrm{E}-04$ \\
\hline $\mathrm{C}_{x} \mathrm{H}_{\mathrm{y}}$ & $6.0 \mathrm{E}-03$ & $1.1 \mathrm{E}+00$ & 2.7E-02 & $1.9 \mathrm{E}+03$ & $1.4 \mathrm{E}-11$ & $8.3 \mathrm{E}+00$ & 1.3E-12 & $9.4 \mathrm{E}-01$ \\
\hline $\mathrm{C}_{\mathrm{x}} \mathrm{H}_{\mathrm{y}}$ aliphatic & & & 4.3E-03 & $9.6 \mathrm{E}+01$ & & & 8.7E-15 & $2.0 \mathrm{E}-10$ \\
\hline $\mathrm{C}_{\mathrm{x}} \mathrm{H}_{\mathrm{y}}$ aromatic & $1.4 \mathrm{E}-01$ & $1.4 \mathrm{E}+00$ & 2.7E-02 & $1.9 \mathrm{E}+03$ & 4.4E-05 & $4.5 \mathrm{E}+00$ & $1.4 \mathrm{E}-07$ & $3.2 \mathrm{E}-02$ \\
\hline $\mathrm{C}_{\mathrm{x}} \mathrm{H}_{\mathrm{y}}$ chloro & $5.0 \mathrm{E}-03$ & 4.5E-01 & $1.0 \mathrm{E}+00$ & $3.5 \mathrm{E}+03$ & 3.3E-05 & $1.3 \mathrm{E}+00$ & 4.3E-06 & $2.6 \mathrm{E}-01$ \\
\hline Cycloalkanes & $6.0 \mathrm{E}-03$ & $1.1 \mathrm{E}+00$ & & & & & & \\
\hline Esters & 2.7E-02 & 4.6E-01 & $1.0 \mathrm{E}+00$ & $3.5 \mathrm{E}+03$ & 3.3E-05 & $1.3 \mathrm{E}+00$ & 4.3E-06 & 2.6E-01 \\
\hline Ethers & $1.8 \mathrm{E}-01$ & 4.5E-01 & & & & & & \\
\hline Heavy metals ${ }^{b}$ & & & $1.7 \mathrm{E}+00$ & $3.4 \mathrm{E}+06$ & $1.9 \mathrm{E}+00$ & $1.7 \mathrm{E}+03$ & $6.1 \mathrm{E}-01$ & $3.0 \mathrm{E}+03$ \\
\hline Ketones & $9.4 \mathrm{E}-02$ & $6.0 \mathrm{E}-01$ & & & & & & \\
\hline $\mathrm{PAHs}$ & & & $5.2 \mathrm{E}-01$ & $8.1 \mathrm{E}+00$ & $5.0 \mathrm{E}-01$ & $3.9 \mathrm{E}+03$ & $1.4 \mathrm{E}-04$ & $3.0 \mathrm{E}+01$ \\
\hline Xylene & $1.0 \mathrm{E}+00$ & $1.1 \mathrm{E}+00$ & 2.7E-02 & $1.2 \mathrm{E}-01$ & 4.4E-05 & 9.3E-05 & 5.3E-07 & $1.3 \mathrm{E}-06$ \\
\hline \multicolumn{9}{|c|}{ Emissions to water } \\
\hline AOX & & & $1.1 \mathrm{E}+00$ & $9.1 \mathrm{E}+03$ & $1.2 \mathrm{E}-02$ & $5.2 \mathrm{E}+03$ & $2.6 \mathrm{E}-07$ & $4.4 \mathrm{E}-01$ \\
\hline Chlorobenzenes & & & $1.1 \mathrm{E}+00$ & $9.1 \mathrm{E}+03$ & $1.2 \mathrm{E}-02$ & $5.2 \mathrm{E}+03$ & $2.6 \mathrm{E}-07$ & 4.4E-01 \\
\hline Chromate & & & $2.1 \mathrm{E}+00$ & $3.4 \mathrm{E}+00$ & $6.9 \mathrm{E}+00$ & $2.8 E+01$ & $n / a^{a}$ & $n / a^{a}$ \\
\hline $\mathrm{C}_{\mathrm{x}} \mathrm{H}_{\mathrm{y}}$ chloro & & & $1.1 \mathrm{E}+00$ & $9.1 \mathrm{E}+03$ & $1.2 \mathrm{E}-02$ & $5.2 \mathrm{E}+03$ & $2.6 \mathrm{E}-07$ & 4.4E-01 \\
\hline Metallic ions & & & 1.7E-02 & $2.3 \mathrm{E}+05$ & $6.9 \mathrm{E}+00$ & $9.1 \mathrm{E}+04$ & $4.8 \mathrm{E}-22$ & 3.3E-16 \\
\hline $\mathrm{PAHs}$ & & & $2.1 \mathrm{E}+00$ & $5.6 \mathrm{E}+00$ & $5.2 \mathrm{E}+02$ & $1.2 \mathrm{E}+06$ & $6.2 \mathrm{E}-06$ & 2.1E-01 \\
\hline Phenols & & & 4.9E-02 & $9.1 \mathrm{E}+03$ & 1.7E+02 & $5.2 \mathrm{E}+03$ & $2.5 \mathrm{E}-06$ & $6.1 \mathrm{E}-02$ \\
\hline Xylenes & & & $3.4 \mathrm{E}-01$ & $4.2 \mathrm{E}-01$ & $5.5 \mathrm{E}-01$ & $6.0 \mathrm{E}-01$ & $4.9 \mathrm{E}-07$ & $1.2 \mathrm{E}-06$ \\
\hline
\end{tabular}




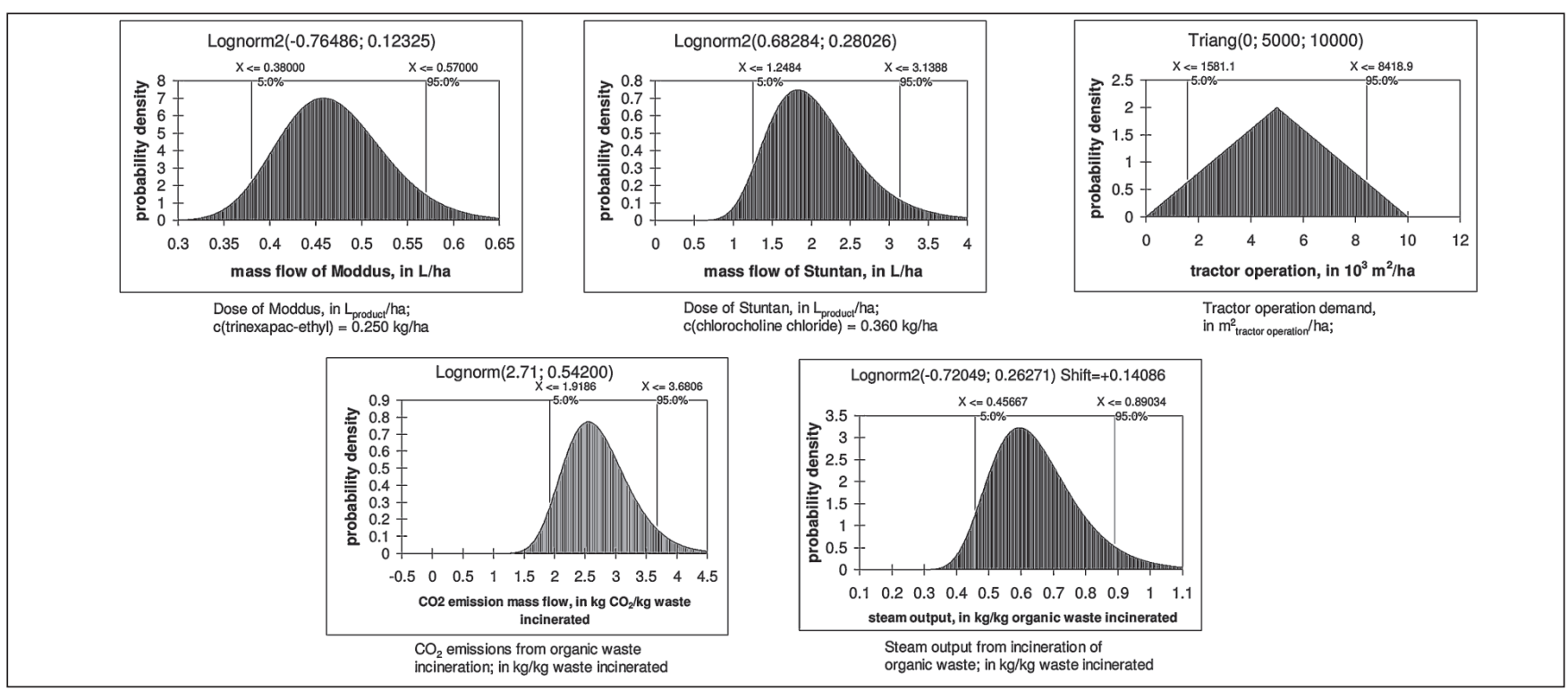

Fig. S1: Probability distributions of important specific parameters in the LCA model. Lognorm2 is a lognormal distribution parameterised with the mean and standard deviation of the lognormal transformed data. Lognorm is a lognormal distribution parameterised with mean and standard deviation of the data in the linear space. Triang is a triangular distribution

authorities [16]. Tractor demand was defined as triangular distribution by expert judgement. Distributions for emissions and steam output from incineration were fitted to on-site data [17] using the @Risk software [18].

\section{Contribution to Variance}

When using Monte-Carlo Simulation, the influence of the input parameters on the results of any model is determined via correlation analysis [19]. Rank-order correlation coefficients [20] were calculated between any input and result parameters in the LCA model with the software @Risk [18].

The contribution of a single uncertain input parameter to the distribution of the result of an impact category was calculated according to

$$
\operatorname{CTV}_{i, j}=r_{i, j}^{2} \cdot\left(\sum_{i=1}^{n_{1}} r_{i, j}^{2}\right)^{-1}
$$

where $\mathrm{CTV}_{\mathrm{i}, \mathrm{j}}$ is the contribution to variance of one uncertain input parameter $i$ to the probability distribution of the result of the impact category $\mathrm{j}$ (dimensionless), $\mathrm{r}_{\mathrm{i}, \mathrm{j}}$ is the rank-order correlation coefficient between the parameter $i$ and the score of impact category $\mathrm{j}$, and $\mathrm{n}_{\mathrm{i}}$ is the number of parameters contributing to the variance in the result of impact category $j$. Contribution to variance measures the influence of an input parameter on the distribution of a result in terms of dispersion as well as in terms of the absolute order of magnitude of the results' values. Input parameters with high contributions to the absolute value of impact scores but very little uncertainty exhibit a minor contribution to variance, which is not corresponding to their contribution to absolute impact scores. However, such parameters do not exist in the model analysed here owing to the use of generic uncertainties.

\section{References}

[1] Frischknecht RE, Bollens U, Bosshart S, Ciot M et al. (1996): Ökoinventare von Energiesystemen (LCIs of Energy Systems). Swiss Federal Office of Energy, Bern, 3rd ed
[2] Simapro 5.0 - LCI Database and LCA-Software 5.0.(2002): Pré consultants B.V., Amersfoort, the Netherlands

[3] Boustead I (1999): Eco-Profiles of Plastics and Related Intermediates. Association of Plastics Manufacturers in Europe (APME), Brussels

[4] Ecoprofiles of the European plastics industry - Polystyrene (1993): PWMI report. PWMI, Brussels, no. 4

[5] Ecoprofiles of the European plastics industry - Polymethyl methacrylate (1997): APME report. APME, Brussels, no. 14

[6] IDEMAT LCI-Database for material information for design and construction purposes (2001): Technical University of Delft

[7] Life Cycle Inventories for Packagings (1998): Part I and II. BUWAL Report. Bundesamt für Umwelt, Wald und Landwirtschaft (BUWAL), Bern, 250, 2nd ed

[8] Bergh V d, Jurgens (1990): LCI on Benzene Production - Dataset Included in the Simapro 5.0 Database. Pré consultants, Amersfoort, NL

[9] Ökoinventare für Verpackungen (LCIs of packaging) (1996): Schriftenreihe Umwelt. Bundesamt für Umwelt, Wald und Landwirtschaft (BUWAL), Bern, 250

[10] Bergh V d, Jurgens (1990): LCI on Sodium Hydroxide Production Dataset Included in the Simapro 5.0 Database. Pré consultants, Amersfoort, NL

[11] Booij H (1993): Produktie van chloor. National Institute of Public Health and Environmental Protection (RIVM), The Hague, NL

[12] Guinée JB, Gorrée M, Heijungs R, Huppes G et al. (2001): CML-Guide to Life Cycle Assessment. Institute of Environmental Sciences (CML), Leiden University, NL

[13] van Oers L (2001): Impact Assessment Factors for the Problem Oriented Approach (CML-baseline method). 2.5 edition. Institute of Environmental Sciences (CML), Leiden University, NL <http://www. leidenuniv.nl $/ \mathrm{cml} / \mathrm{lca} 2 / \mathrm{index} . h \mathrm{html}>$

[14] Huijbregts MAJ (2001): Uncertainty and variability in environmental life-cycle assessment. Dissertation, Universiteit van Amsterdam, Faculteit natuurwetenschappen, wiskunde en informatica, Amsterdam, NL

[15] Slob W (1994): Uncertainty analysis in multiplicative models. Risk Analysis 14, 571-576

16] Pflanzenschutzmittelverzeichnis (Directory of Plant Protection Products) (2002): Bundesamt für Landwirtschaft (BfL), Bern

[17] Data on Utility Inputs into and Emissions from the Chemical Waste Incinerator and the Wastewater Treatment Plant at the Monthey Production Site (2000): CIMO SA, Monthey, CH

[18] @Risk 4.5 - Risk Analysis Add-in for Microsoft Excel (2001): Palisade Corporation, Newfield, NY, USA

[19] Morgan MG, Henrion M (1990): Uncertainty. Cambridge University Press, Cambridge

[20] Hartung J, Elpelt B, Klösener K-H (1995): Statistik. 10th ed. R. Oldenburg Verlag, München 